\title{
Use of epoxysepharose for protein immobilisation
}

\author{
G. S. MURTHY* and N. R. MOUDGAL \\ Center for Advanced Research in Reproductive Biology (ICMR), Laboratory of \\ Endocrine Biochemistry, Department of Biochemistry, Indian Institute of Science, \\ Bangalore 560 012, India \\ MS received 3 August 1985; revised 15 May 1986
}

\begin{abstract}
Epoxy Sepharose, an activated affinity matrix which has been used for immobilisation of carbohydrates has been tried for immobilisation of proteins. Under normal conditions of coupling at neutral or alkaline $\mathrm{pH}$ proteins do not couple to epoxy Sepharose. However, a very high salt concentration during coupling allows the binding of proteins to epoxy Sepharose at a $\mathrm{pH}$ as low as 8.5. Increasing ionic strength and/or $\mathrm{pH}$ facilitates the binding. The bioactivity of the proteins is not destroyed by the immobilisation. This matrix, unlike cyanogen bromide-Sepharose, retains its ability to bind albumin by $80-90 \%$ even after 60 days of storage in aqueous suspension at $4^{\circ} \mathrm{C}$. Its capacity to bind proteins is comparable to that of cyanogen bromide-Sepharose.
\end{abstract}

Keywords. Epoxy Sepharose; affinity matrix; protein immobilisation.

\section{Introduction}

Use of affinity techniques has become a routine laboratory method in biochemical research. Widely used activated solid supports have been cyanogen bromide (CNBr)-Sepharose for protein coupling and epoxyactivated Sepharose for carbohydrates.

Preparation of CNBr-Sepharose in a laboratory involves use of pungent and poisonous cyanogen bromide (fresh) and an activation procedure which is hazardous. In addition, the activated material so obtained has a very short life and needs to be used for coupling within couple of minutes (Axen et al., 1967; Jakoby and Wilchek, 1974). The other activated Sepharose, namely, epoxy Sepharose (EPS) is used for coupling of ligands through hydroxyl groups (Sundberg and Porath, 1974; Vretblad, 1976). This support has been characterised to be capable of binding to amino, hydroxyl and sulphydral groups (Vretblad, 1976; Landt et al., 1978; Simons and Vander Jagdt, 1977), and yet this has never been used earlier for protein coupling. A chance observation that EPS bound well to cytochrome $\mathrm{C}$ in concentrated sodium carbonate solution prompted us to investigate the coupling of proteins to EPS. In the present paper we report on the use of EPS for the immobilisation of proteins.

\footnotetext{
* To whom correspondence should be addressed.

Abbreviations used: CNBr, Cyanogen bromide; EPS, epoxy Sepharose; oLH, ovine leutinising hormone; IgG, immunoglobulin G; oFSH, ovine follicle stimulating hormone; NSS, normal sheep serum.
} 


\section{Materials and methods}

Trypsin, albumin, haemoglobin, trypsin inhibitor and butanedioldiglycidyl ether were all purchased from Sigma Chemical Co., St. Louis, Missouri, USA. All other reagents used were analytical reagent grade. Sepharose 4B was a product of Pharmacia, Sweden.

\section{Preparation of EPS}

EPS was prepared by a standard procedure (Axen et al., 1967). Briefly $40 \mathrm{~g}$ of Sepharose 4B was washed well with distilled water and suspended in $2 \mathrm{M}$ sodium hydroxide $(40 \mathrm{ml})$. Butanedioldiglycidyl ether $(10 \mathrm{ml})$ was added and the suspendsion was stirred overnight at room temperature. The suspension was then filtered on a sintered funnel, washed extensively with water until the filtrate was neutral (2 litres of water), then with acetone $(200 \mathrm{ml})$ and finally with $500 \mathrm{ml}$ of water. The gel obtained was stored as aqueous suspension at $4^{\circ} \mathrm{C}$ for further use.

\section{Binding of proteins and tryptophan to EPS}

EPS $(200-300 \mu \mathrm{l})$ in a $3 \mathrm{ml}$ test tube was washed thoroughly with the required buffer and centrifuged to obtain a compact pellet. This pellet was dispersed in $100 \mu \mathrm{l}$ of buffer and protein solution $(200 \mathrm{mg} / \mathrm{ml}$ albumin, $100 \mathrm{mg} / \mathrm{ml}$ haemoglobin, $75 \mu$ mol tryptophan) taken in the same buffer $(100 \mu \mathrm{l})$. This was intermittently vortexed and reaction was allowed to take place at room temperature. The suspension was diluted with $2 \mathrm{ml}$ of phosphate buffer $(0.2 \mathrm{M}, \mathrm{pH} 6.5)$ and spun. The optical density of the clear supernatant was measured. As control, Sepharose (200-300 $\mu \mathrm{l})$ with protein and buffer was also incubated and processed identically. The decrease in the absorbance between control and experimental sample was used to quantitate the protein bound to the matrix.

\section{Preparation of immobilised oLH antisera on Sepharose}

$1 \mathrm{ml}$ of ovine leutinising hormone $(\mathrm{oLH})$ antisera raised in the monkey was diluted to $5 \mathrm{ml}$ with water and the immunoglobulin fraction from this antisera was precipitated by adding $5 \mathrm{ml}$ of $25 \%$ polyethylene glycol at $4^{\circ} \mathrm{C}$. The precipitate was spun at $5000 \mathrm{~g}$ for $30 \mathrm{~min}$ and the supernatant discarded. The pellet was collected

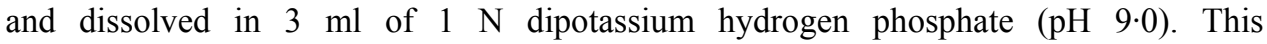
immunoglobulin $\mathrm{G}$ ( $\mathrm{IgG}$ ) enriched fraction was coupled to $2 \mathrm{ml}$ of freshly prepared EPS equilibrated with the above buffer. The reaction was carried out at room temperature under mild shaking. The gel was washed well with water and stored at $4{ }^{\circ} \mathrm{C}$ for further use. The extent of binding as measured by the decrease in the absorbance of the supernatant was about $70 \%$.

\section{Binding of trypsin to matrix bound trypsin inhibitor}

Trypsin inhibitor coupled to EPS (4 mg trypsin inhibitor on $200 \mu \mathrm{l}$ of EPS) was reacted with $300 \mu \mathrm{l}$ of trypsin $(1.65 \mathrm{mg})$ in $0 \cdot 1 \mathrm{M}$ sodium bicarbonate solution for $30 \mathrm{~min}$. The reaction mixture was diluted with $2 \mathrm{ml}$ water and the absorbance of the supernatant measured at $280 \mathrm{~nm}$. The decrease in the $\mathrm{A}_{280}$ of the supernatant 
was used to calculate the amount of trypsin bound to the matrix. As control trypsin $(1.65 \mathrm{mg})$ was incubated with Sepharose $(200 \mu \mathrm{l})$ and processed identically.

\section{Removal of oLH antibodies from ovine follicle stimulating hormone antisera}

oLH coupled to EPS was washed thoroughly with water (4 mg oLH coupled to $2 \mathrm{ml}$ EPS) and mixed with $5 \mathrm{ml}$ of ovine follicle stimulating hormone (oFSH) antisera. The mixture was initially shaken overnight at room temperature. The supernatant from this mixture was collected. The binding of [I]- oLH to this antiserum before and after treatment was done to assess the extent of removal of the oLH antibodies.

\section{Determination of enzyme activity}

Enzyme activity of glucose oxidase coupled to EPS was determined by the standard procedure. The formation of colour on incubation with glucose, peroxidase and $o$-dianisidine was taken as a positive indication for the presence of activity. Quantitative analysis of the enzyme activity was not undertaken.

\section{Results}

Binding of haemoglobin to EPS at alkaline $\mathrm{pH}$ conditions are shown in table 1 . The coupling of the protein is insignificant even at $\mathrm{pH} 12$ and nothing at $\mathrm{pH}$ values below 11, clearly demonstrating that EPS does not bind to proteins under normal conditions of coupling. Similar results were also obtained when coupling of albumin was attempted.

Table 1. Binding of haemoglobin to EPS at $\mathrm{pH} 10-12$.

\begin{tabular}{lc}
\hline $\mathrm{pH}^{*}$ & $\begin{array}{c}\text { Haemoglobin bound } \\
\mathrm{mg} / \mathrm{ml} \text { gel }\end{array}$ \\
\hline 12 & $1 \cdot 5$ \\
11 & $0 \cdot 0$ \\
10 & $0 \cdot 0$ \\
\hline & \\
Reaction was carried out in \\
$0 \cdot 01 \mathrm{M}, 0 \cdot 001$ M and $0 \cdot 0001 \mathrm{M}$ \\
sodium hydroxide, respectively. \\
$20 \mathrm{mg}$ of haemoglobin was reacted \\
with $0 \cdot 5 \mathrm{ml}$ of EPS. Time of reac- \\
tion was $18 \mathrm{~h}$.
\end{tabular}

Figures 1 and 2 show the effect of ionic strength on the binding of proteins (albumin and haemoglobin). Increasing salt concentration facilitates the coupling (figure 1). Increasing the ionic strength by neutral salts also increases the binding markedly (figure 2), demonstrating that the coupling is facilitated by increasing ionic strength (salt concentration). 


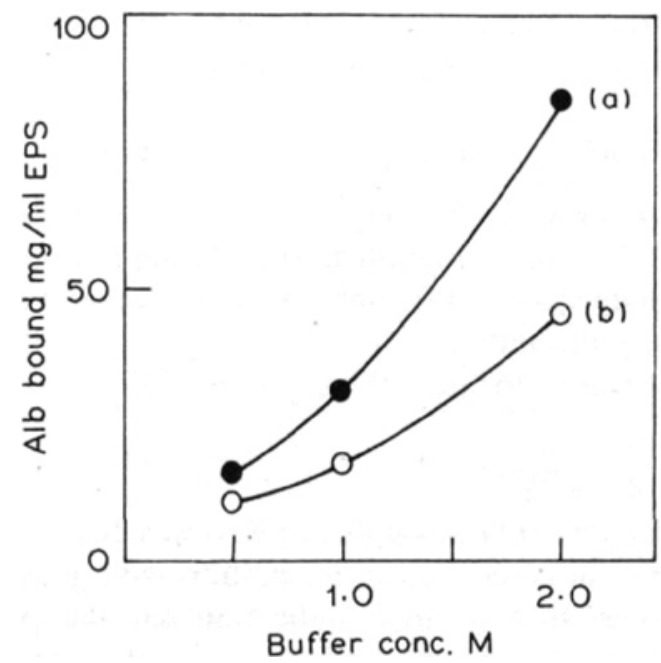

Figure 1. Effect of buffer concentration on binding of albumin to EPS. Curve (a), $2 \mathrm{M}$

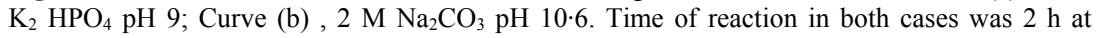
room temperature.

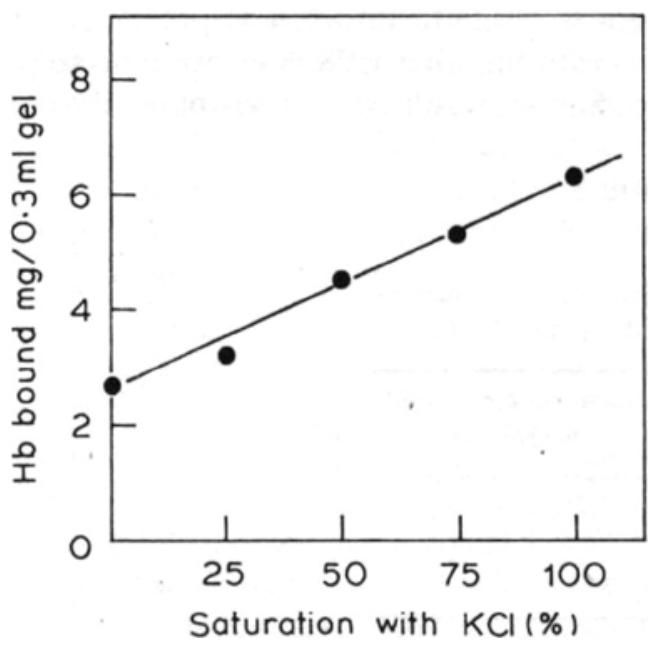

Figure 2. Effect of salt concentration on binding of haemoglobin to EPS: Conditions of reaction: $2 \mathrm{M}$ sodium carbonate, buffer $\mathrm{pH} 9.0$ and time of reaction $1 \mathrm{~h}$.

Figures 3 and 4 show the effect of $\mathrm{pH}$ and time on the coupling efficiency of proteins to EPS. It is evident from the figures that higher $\mathrm{pH}$ and longer time increases the efficiency of binding markedly.

Binding of haemoglobin as a function of its concentration is shown in figure 5 (curve a). It indicate that the binding of the protein is dependent on its concentration during coupling (curve a). Within the range of concentrations used, the haemoglobin bound as a per cent of each concentration remained essentially constant (curve b). 


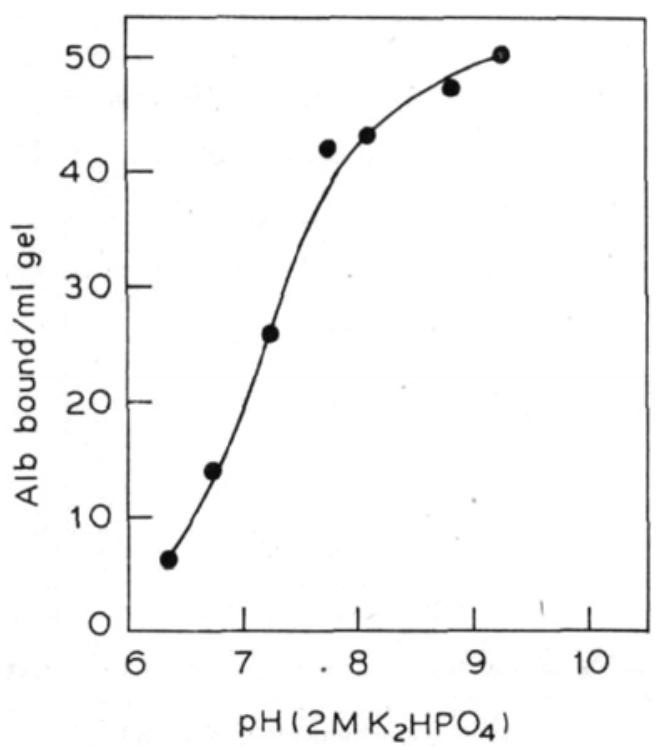

Figure 3. Effect of $\mathrm{pH}$ on the binding of albumin to EPS: Conditions of reaction: $2 \mathrm{M}$ potassium phosphate buffer $(\mathrm{pH} \sim 9)$ and time of reaction $2 \mathrm{~h}$.

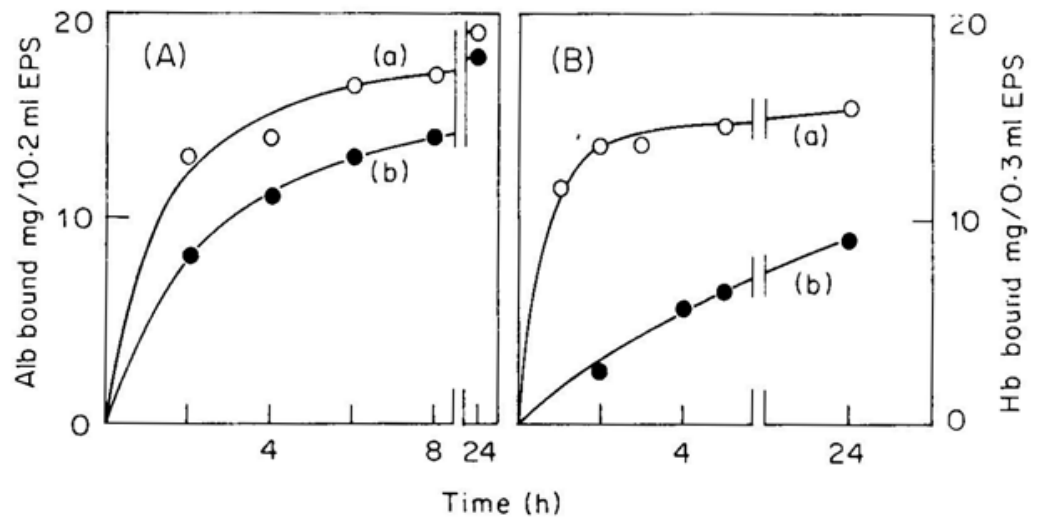

Figure 4. Kinetics of binding of proteins to EPS. A. Binding of albumin. Curve (a), 2 M potassium phosphate, $\mathrm{pH}$ 9; curve (b), $2 \mathrm{M}$ potassium phosphate, $\mathrm{pH}$ 8. B. Binding of haemoglobin. Curve (a), $2 \mathrm{M}$ sodium carbonate $\mathrm{pH} 9$ saturated with $\mathrm{KCl}$; curve (b), sodium carbonate $\mathrm{pH}$. saturated with $\mathrm{KCl}$.

Coupling efficiency of tryptophan to EPS is depicted in figure 6. Saturation of binding occurs at $40 \mu \mathrm{M}$ concentration of tryptophan and the capacity of the gel as measured by this method is $8-10 \mu \mathrm{mol} / \mathrm{ml}$. Unlike in the case of proteins the binding of tryptophan to EPS was found to be ionic strength independent.

Table 2 presents the binding of normal sheep serum (NSS) and the IgG fraction. of NSS and other proteins to EPS. The binding of $\mathrm{IgG}$ is almost complete while the binding of the NSS is nearly $50 \%$. It is also seen that binding of proteins can occur 


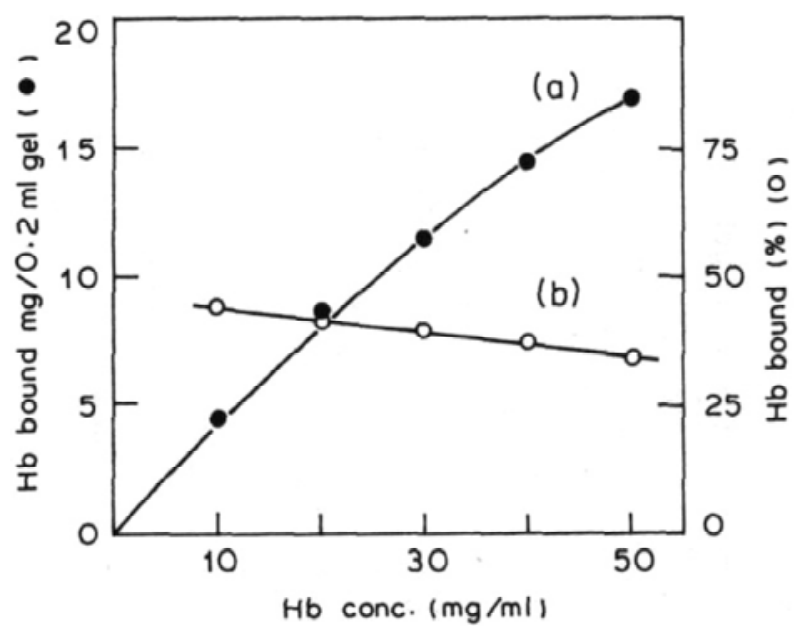

Figure 5. Binding of haemoglobin as a function of its concentration: Conditions of reaction: $1 \mathrm{M}$ potassium phosphate buffer, $\mathrm{pH}$ 9, time of reaction $20 \mathrm{~h}$ at room temperature. Curve (a), Haemoglobin bound $/ 0 \cdot 2 \mathrm{ml}$ gel; curve (b), per cent of haemoglobin bound.

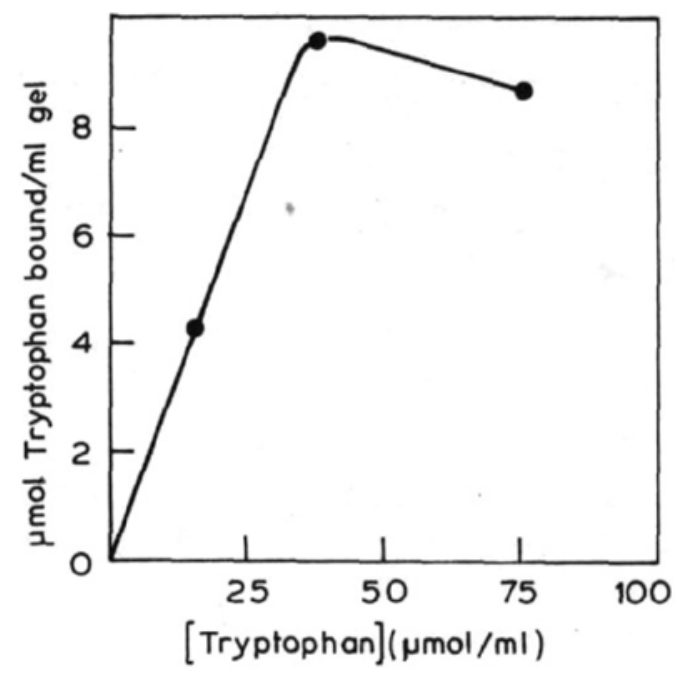

Figure 6. Binding of tryptophan of EPS: Buffer- $0 \cdot 1 \mathrm{M}$ carbonate $\mathrm{pH} 10 \cdot 5$; time, $20 \mathrm{~h}$ at room temperature. For all calculations a molar extinction coefficient of 5400 at $280 \mathrm{~nm}$ was employed.

at $\mathrm{pH}$ around 9. In these proteins, enzyme activity of glucose oxidase, trypsin binding activity of trypsin inhibitor, immunoactivity of oLH were tested after coupling to EPS and found to be intact, clearly indicating retention of activity after coupling. Quantitative analysis of the binding data indicated that trypsin inhibitor-EPS could bind $1 \mathrm{mg}$ of trypsin. Likewise the oLH antibody coupled to EPS bound $800 \mu \mathrm{g}$ of oLH (the capacity of the antisera coupled as measured by 
Table 2. Coupling of proteins to epoxysepharose.

\begin{tabular}{lccccccccccc}
\hline & \multicolumn{10}{c}{ Protein used } \\
\cline { 2 - 10 } & $\begin{array}{c}\text { Glucose } \\
\text { oxidase }\end{array}$ & $\begin{array}{c}\text { Trypsin } \\
\text { inhibitor }\end{array}$ & Ovine & LH $^{b}$ & IgG & Trypsin & oLH a/s & $\begin{array}{c}\text { Sheep } \\
\text { IgG }\end{array}$ & $\begin{array}{c}\text { Sheep } \\
\text { serum }\end{array}$ \\
\hline $\begin{array}{l}\text { pH } \\
\text { Protein } \\
\text { added } \\
\text { (mg) }\end{array}$ & 8.8 & 9.6 & 9.5 & 10.6 & 9.5 & 10.6 & 10.0 & 9.0 & 9.0 & 10.6 & 10.6 \\
$\begin{array}{c}\text { Protein } \\
\text { bound } \\
\text { (mg) }\end{array}$ & 12.0 & 12.0 & 9.5 & 9.5 & 7.0 & 7.0 & 5.0 & 20.0 & 25.0 & 7.0 & 16.0 \\
\hline
\end{tabular}

a The immobilised trypsin inhibitor bound $1 \mathrm{mg}$ trypin.

${ }^{b}$ This oLH was used for the removal of the contaminating oLH antibodies from oFSH a/s. The removal of the oLH antibodies was quantitative.

$c$ The insolubilised antiserum removed quantitatively the oLH contamination $(800 \mu \mathrm{g})$ from oFSH preparation $(10 \mathrm{mg})$.

In all these cases $0.3 \mathrm{ml}$ of EPS was used for coupling in $1 \mathrm{M}$ potassium phosphate, overnight.

Scatchard analysis was $500-600 \mu \mathrm{g}$ ). Thus the binding activity of trypsin inhibitor is partially lost $(50 \%)$ on immobilisation whereas the immunological activity of the antibody is retained completely after immobilisation on EPS.

Figure 7 shows the stability of the EPS and CNBr-Sepharose stored in suspension. EPS retains to a large extent the capacity to bind to albumin even after 90 days, whereas CNBr-Sepharose loses it within a couple of days.

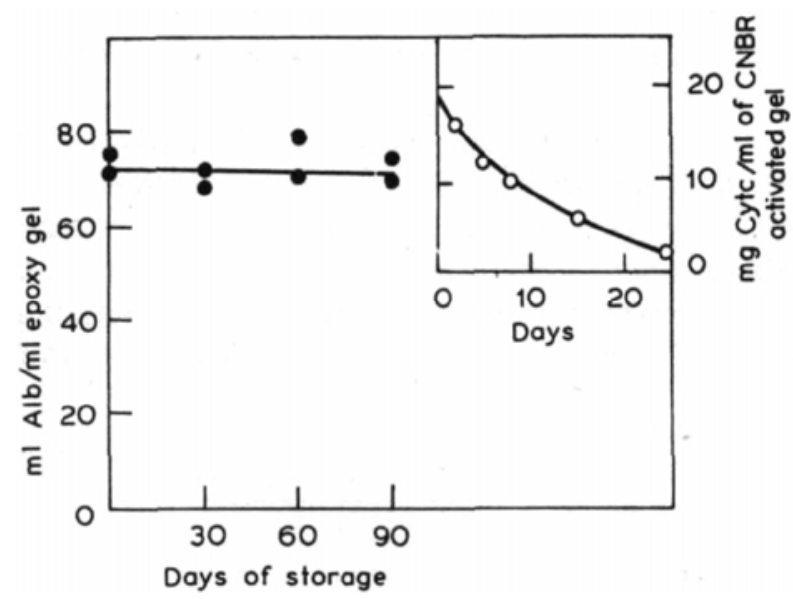

Figure 7. Effect of storage of EPS and CNBr-Sepharose (in aqueous solution at $4^{\circ} \mathrm{C}$ ) on protein binding capacity. Binding was carried out as described under methods. Albumin and cytochrome $\mathrm{C}$ were used for $\mathrm{EPS}$ and $\mathrm{CNBr}$-Sepharose, respectively. Inset shows the stability of CNBr-Sepharose. 


\section{Discussion}

The data presented demonstrates that EPS can be used for coupling of proteins to Sepharose matrix. So far its use has been limited to coupling carbohydrates through their hydroxyl groups. This could presumably be due to the fact that under normal conditions of coupling ( $\mathrm{pH} 8-9,0 \cdot 1 \mathrm{M}$ sodium bicarbonate) EPS does not bind to proteins (table 1). The parameters which appear to facilitate remarkably the coupling are ionic strength and $\mathrm{pH}$ (figures 2 and 3). High ionic strength facilitates the coupling further (figure 4). The coupling of proteins to the matrix can be effected at $\mathrm{pH}$ values as low as 8-9, where most proteins retain their structure or biological activity. The capacity of the matrix for binding albumin and haemoglobin is quite comparable to that of $\mathrm{CNBr}-\mathrm{Sepharose}$.

Albumin and haemoglobin coupled to EPS could not be dissociated by $5 \mathrm{M}$ potassium iodide or glycine $\mathrm{HCl}$ buffer $\mathrm{pH} 2 \cdot 8$. Thus coupling of proteins to the matrix could be either through the hydroxyl group of serine or threonine, or the $\alpha$ or $\in$ amino groups. As yet there is no clear proof to implicate any one of these groups in this reaction. However, it is observed (Murthy, G. S., unpublished results) that the amino groups of albumin and other proteins can be completely blocked by adding the epoxy reagent, favouring the amino group as the possible point of attachment.

Coupling of proteins to EPS does not cause destruction of activity of the proteins (table 2). This clearly indicates the essential feasibility of using this matrix for affinity purification of biologically active molecules.

The stability of EPS in suspension is very much more than that of $\mathrm{CNBr}$ Sepharose (figure 7). Its preparation is also very easy. For these reasons preparation and use of EPS in affinity techniques is more convenient than that of $\mathrm{CNBr}-$ Sepharose in laboratories. Under conditions where the proteins are insoluble at relatively high ionic strength, EPS may be only of limited use.

The stability of the linkage between the epoxy group and the amino group is expected to be much stronger than that between the amino and the cyanate ester group (active groups in the $\mathrm{CNBr}$-Sepharose). Thus it is possible that the linkage between the protein and EPS could be stronger than that between $\mathrm{CNBr}$-Sepharose and protein.

EPS $\mathrm{c}$ an be easily used for the preparation of AH-Sepharose, $\mathrm{CH}-\mathrm{Sepharose}$ etc by coupling with appropriate ligands, by procedures described for coupling of trytophan. Preparation of lysine-Sepharose, arginine-Sepharose and histidineSepharose have been done using the above procedure (Murthy, G. S., unpublished results). Thus EPS provides a versatile affinity matrix which can be easily prepared in the laboratory and used for both protein and carbohydrate coupling.

\section{References}

Axen. R., Porath, J. and Ernback. S. (1967) Nature (London), 214, 1302.

Porath, J. (1974) Methods Enzymol., 34, 13.

Kohn, J. and Wilchek. M. (1982) in Affinity chromatography and related techniques (eds T. C. J.

Gribnau, J. Visscr and R. J. F. Nivard), (North Holland: Elsevier Publishing Company) p. 235.

Landt, M., Boltz, S. C. and Butler. L. G. (1976) Biochemistry, 17, 915.

Simons. P. C. and Vander Jagdt, D. L. (1978) Anal. Biochem., 82, 334.

Sundberg. L. and Porath. J. (1974) J. Chromatogr., 90, 87.

Vretblad, P. (1976) Biochim. Biophys. Acta, 434, 169. 